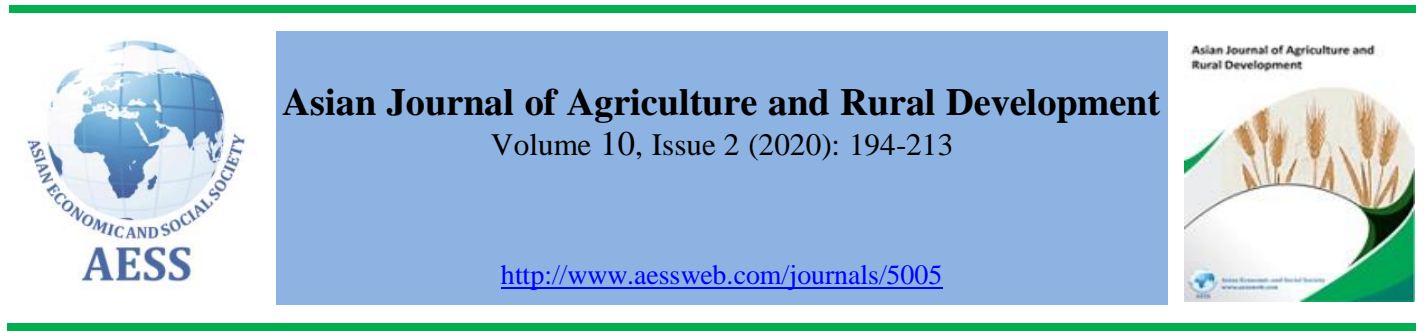

\title{
ANALYSIS OF POLICY INTERVENTIONS IN AGRICULTURE AND ICT BASED MECHANISTIC APPROACH TOWARDS SUSTAINABILITY: AN INDIAN PERSPECTIVE
}

Acharya Balkrishna a, a Patanjali Herbal Research Department, Patanjali Research Institute, Rashmi Mittal a, Haridwar, India

Ashwani Kumar a, Deepti Singh a, Vedpriya Arya ${ }^{a}$

\section{ARTICLE HISTORY:}

Received: $16-\mathrm{Jan}-2020$

Accepted: 01-Apr-2020

Online available: $29-\mathrm{Apr}-$ 2020

\section{Keywords:}

Farmers,

Indian government,

Subsidies,

Welfare schemes
- $₫$ vedpriya.arya@prft.co.in (Corresponding author)

\begin{abstract}
The present work stressed the negative prospects of the green revolution in India because of which despite having surplus productivity, there is a shortage of approximately $39 \%$ of food in comparison to demand. The present study investigated both qualitative and quantitative data regarding the input and output of agriculture to determine the currently existing gaps. Data from Government Organizations, Surveys, Audit reports were collected and evaluated. The analysis revealed that past policy interventions have collapsed in uplifting the farmer's income which has caught farmers into financial crisis. Under these circumstances, the farmer's growth is a matter of concern for policymakers. To overcome the present gap, the current Government has taken several new initiatives regarding organic agriculture and exemption of farmers from mandis to benefit the farmer which is expected to be proved as a milestone in uplifting the growth of Indian agriculture system. Present study aimed to propose a digitalized mechanistic approach to bring synchronization among Government, producer and consumer. Objective of the present study is to develop a mirrored view between Government initiatives and farmers for sustainable development of agriculture and people associated with them.
\end{abstract}

\section{Contribution/ Originality}

The present study acts as a reflective analysis of policies and schemes initiated for benefitting the farmers and thereby proposes a digitalized mechanistic approach to overcome the limitations associated with it.

DOI: $10.18488 /$ journal.1005/2020.10.1/1005.1.194.213

ISSN (P): 2304-1455/ISSN (E):2224-4433

How to cite: Acharya Balkrishna, Rashmi Mittal, Ashwani Kumar, Deepti Singh and Vedpriya Arya (2020). Analysis of policy interventions in agriculture and ICT based mechanistic approach towards sustainability: an Indian perspective. Asian Journal of Agriculture and Rural Development, 10(1), 194-213.

(C) 2020 Asian Economic and Social Society. All rights reserved 


\section{INTRODUCTION}

India has a hefty disparate agricultural sector, which contributes to about $16 \%$ of India's GDP and $10 \%$ of export earnings. In the global market, India ranks amongst topmost countries in crop production. In the case of cereals, India ranks third in the world market and contributes $11.1 \%$ to the country's economy. Indian scenario has experienced an abrupt increase in food grain production from 51 to 285 million tonnes during the tenure of 1950-51 to 2017-18 (Moray, 2019). An astounding endeavor of farmers plays a vital role in the success of the agriculture sector and their income is directly related to crop. An analysis of the productivity factor provides an insight into the nature and drivers of agriculture growth. Production efficiency of the Indian agriculture sector has enormously enhanced from 1980 till today with an exception of the period from 1997 to 2003 wherein the productivity declined due to weather shocks. India dominates over other countries in terms of agricultural exports. Agriculture trade has grown from USD 3.6 to 22 billion from 2000 to 2013. There exists a variation between the export of wheat and coarse grains, and have often reached high levels, currently, the export of protein meal is flourishing rapidly. India has recently become one of the top bovine meat exporters. An escalation in agricultural productivity and industrial growth greatly contributed towards the country's economy which ultimately leads to the decline in the poverty rate. The poverty rate has almost reduced to half, falling from around 55 to around $28 \%$ over the past 10-year. Despite the impressive growth and development, still, a large population of India is under the poverty line. India has a high population pressure on land and other resources to fulfill its food and other developmental needs (Government of India and Sally, 2018).

Currently, a major crisis to be seen in farming is farmer's income. The average income of a farmer is observed to be about $65 \mathrm{USD} / \mathrm{month} /$ family. There also have been reports about people moving out of agriculture in the past 20 years and no other sector has given them breakthrough employment as a result of which farmers are wandering from one place to another in search of work opportunities. Conclusively it can be said that the collapse of public institutions and the failure of agriculture policies that are running from several decades in accomplishing the needs of farmers have caught Indian farmers in crisis. The present work is an attempt to highlight the production, availability, and shortage of food in the country and the overview of a scheme initiated for the welfare of farmers and the major loopholes associated with it which are held responsible for its failure (Deshpande, 2017; Chait, 2019). The secondary data was obtained with the help and positive prospects of Governmental organizations, surveys, and respective Ministries, without their support it would have been impossible to frame the present study.

\section{PRODUCTION, AVAILABILITY AND FOOD CRISIS IN INDIA}

Agriculture productivity has sharply increased in the past few decades. The yield of rabi crops has been contributing significantly to the total foodgrain production over the 1970-71 to 2016-17 and a similar trend has been observed in yield of Kharif food grain (Figure 1). 


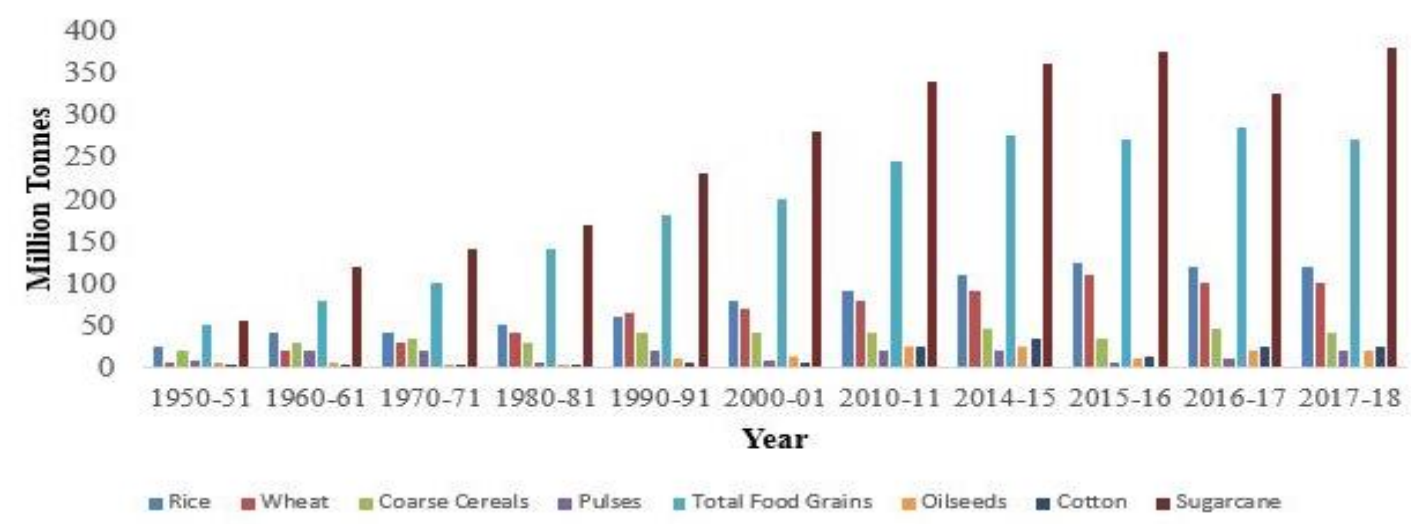

Figure 1: Year-wise production of Rabi and Kharif crops in India

As India's agriculture productivity was compared with other countries it was observed that it has grown at a slower pace as compared to others. For instance, the yield for rice has increased from 1.3 to 4.9 tonnes/ha in Brazil whereas in India it increased from 2.0 to 3.6 and in China's productivity grew from 4.3 to 6.7 (Figure 2) (Government of India, 2019; Indian Council for Research on International Economic Relations, 2018).

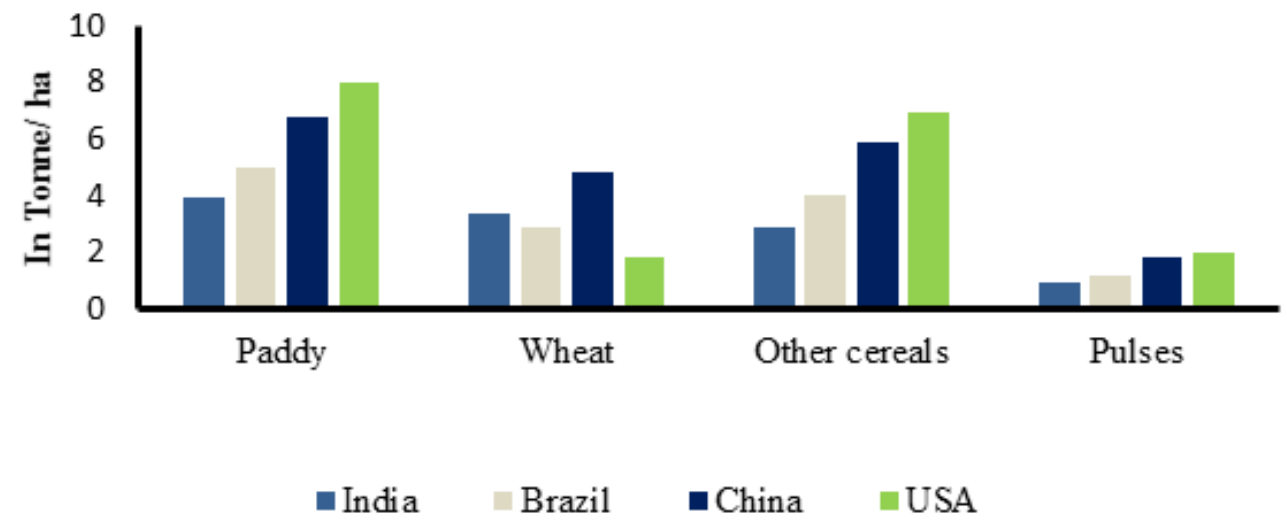

\section{Figure 2: Yield of food grains in different countries in 2014-15 (Tonnes/ha)}

Apart from all this, India's production is surplus to meet the need of the present population. In 2018, India's population was estimated to be 1.35 billion. On average in India, 1 person consumes $101.7 \mathrm{~g}$ food grains per day thereby constituting an average of $37 \mathrm{~kg}$ per year. So the total population of India (2018) requires 49.52 tonnes to meet their food requirement. Total production of food grains (wheat and rice) in 2018 remained to be 614386000 tonnes per year which are abundant to meet the country's requirement. Wastage, hoarding, and export also affect availability. Majorly food wastage which constitutes approximately $40 \%$ of total production whereas hoarding and export which constitutes an average of 0.5 and $0.02 \%$ respectively act as the major factors held responsible for food shortage (Planning commission Government of India, 2015; PRS Legislative Research, 2019). Approximately the Indian population suffers from 193 lakh tonnes of food shortage every year and the ratio is increasing rapidly at a faster pace. To encounter the issue of the food crisis, the Government has initiated several schemes for the farmer's welfare and a brief description of it has been highlighted in the upcoming sections of the article. 


\section{GOVERNMENT SCHEMES AND POLICIES FOR THE WELFARE OF FARMERS}

Farmers are enormously smashed due to norms and regulations imposed by the domestic market and export trade restrictions, which collectively lead to forceful imposition of producer prices that are below the market value of their products. Agriculture Ministry of India has initiated several programs such as subsidies over different commodities, more than 20 schemes at the National level and various others at the State level have been initiated with the motto of farmer's welfare. Despite such tremendous efforts and the expenditure of such a high ratio of the Indian economy, the farmer's condition has not improved so far. Unfortunately, in the Indian Governance system, the process of policy formation is greatly influenced by political considerations, and realities are often ignored at the cost of the financial health of the economy and social equity among farmers. Ground trusting of the policies and schemes and their loopholes have been briefly mentioned in the upcoming section of the article.

\subsection{Subsidies and its influence over commodities}

The subsidy is a Government incentive paid to agricultural organizations, agribusinesses, and farms to supplement their income, to manage the supply of agricultural products. Subsidies play a crucial role in the country's economy and are vital for farmer's welfare. Producer and consumer subsidies both are important at their respective places for reinforcing the equities, income level and to support disadvantaged sections. In terms of income transfer also, subsidies play a crucial role to provide benefits to the depressed section of society.

According to the Government's budget of 2019-2020, subsidy bill on food, fertilizer, and fuel is estimated to go up by $13.32 \%$ to 39.35 billion USD. An immense increase has been made in fuel subsidy of the total subsidy bill which is depicted to be around 4.89 billion USD from the revised estimate of 3.24 billion USD for 2018-19. When the fuel subsidy bill was considered it was observed that the LPG subsidy is expected to be of 4.30 billion USD for 2019-2020 in comparison to 2.65 billion USD which was in 2018-19. Whereas a slight decline in kerosene subsidy was observed in comparison to the previous year which was previously 593.51 million USD and now it reduced to 585.55 million USD. In the case of the food subsidy bill, an increase of $7.54 \%$ to 24.03 billion USD for the current year has been observed from the previous estimate of 22.34 billion USD. Similarly, the fertilizer subsidy is projected to be enhanced by $14.14 \%$ to 10.43 billion USD in 2019-20 from the revised estimate of 9.14 billion USD in the last fiscal. Out of this allocation, urea subsidy itself constitutes an average of 7 billion USD and nutrient-based subsidies of 3.43 billion USD, as per the Budget document (Figure 3) (Government of India, 2019; Karnik and Lalvani, 1996). 


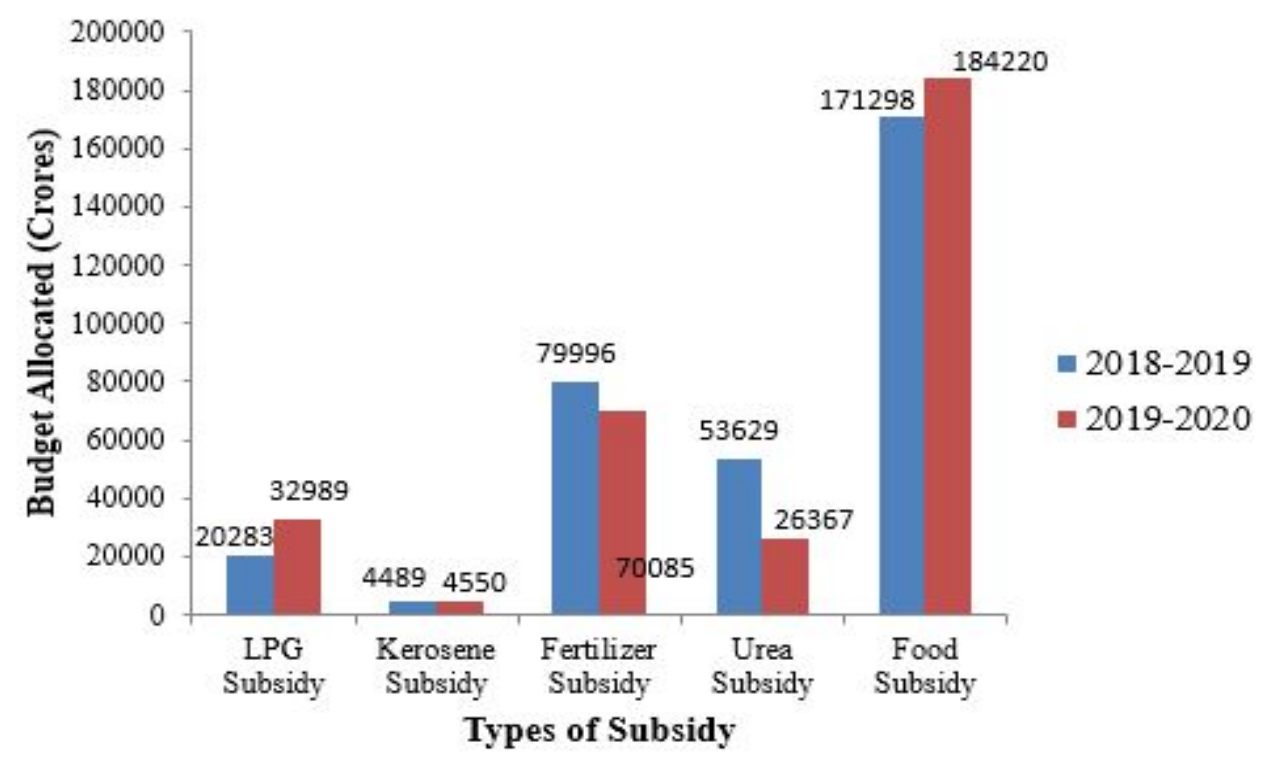

Figure 3: Subsidy provided on different commodities during 2018-2020 by Government

\subsubsection{An insight of agriculture subsidies provided by the Indian government}

Despite the allocation of a large number of subsidies to fertilizers, power, and irrigation, a current policy couldn't improve farmer's state rather it has reduced gross farm revenue by $6 \%$ and it was consistently observed during 2014-16. This type of support to producers is generally measured in terms of share transfer from consumers and taxpayers in gross farm revenues and is generally comprised of $6.9 \%$ of gross farm receipts and $-13.1 \%$ of market price support. Collectively, a negative producer support estimate (PSE) has been observed which is greatly affecting farmer's state. It was predicted that to avail the maximum benefit of it, consumer subsidies need to be provided directly to the intended beneficiaries either in the form of food stamps, to avoid stealing of agricultural commodities available in the public distribution system and to provide the consumers with the choice of food which they would like to purchase.

The benefits of Government schemes and policies are being mostly given to big farmers having landholding of 10 acres (4.05 hectares) and above. Only 10 percent of poor and small farmers with an average landholding of 1-4 acres ( 0.4 to 1.6 ha) have been benefited from Government schemes and subsidies. Farmers blamed the State and Central Governments for their present condition as 74\% of them alleged they do not get any farming-related information from officials of the agriculture department. $62 \%$ of farmers were not even informed about the minimum support price strategy of Government and among those who have heard about MSP, $64 \%$ were not satisfied with the price which the Government offers (Sharma, 2004).

\subsection{Government-sponsored schemes for the welfare of farmers}

The government of India has made farmer's welfare as their utmost priority and is implementing several farmers' welfare schemes to strengthen the agriculture sector and to improve their economic conditions. The government has embarked on several new initiatives and is motivating farmers to opt for the new projects and is self-financing a part of the total cost of the project (Figure 4). 


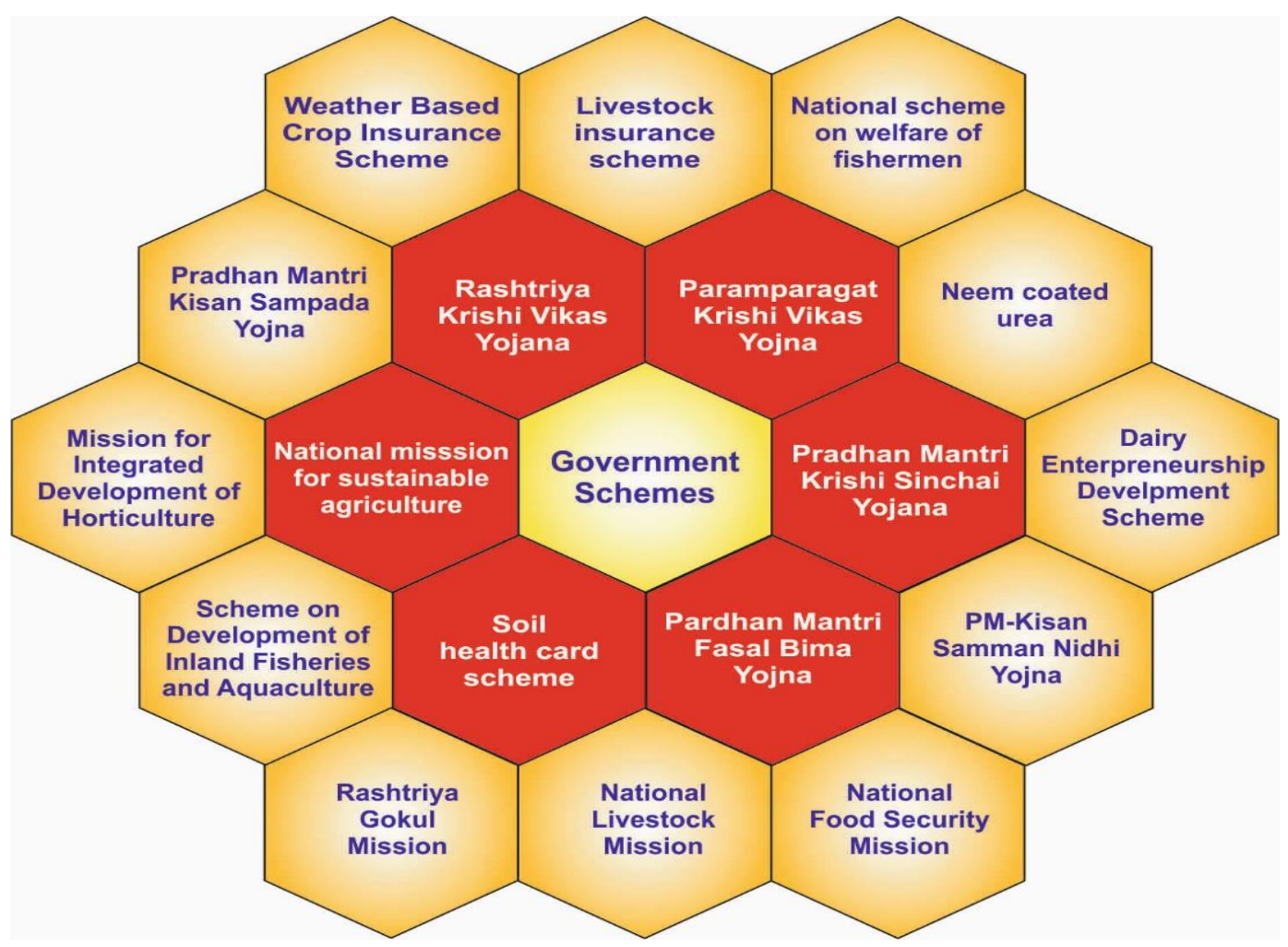

Figure 4: Schemes initiated by Government for farmer's welfare

The motto of initiating these projects is to enhance the capital investment, sustained income flow, and employment areas of national importance. The schemes initiated by the Government have been listed below (Table: 1). (Government of India, 2014; Amarender, 2017; Government of India (PMKSY), 2019; Business standard, 2019; Government of India (SHC), 2019; Government of India (NMSA), 2018; Government of Haryana Pashudhan, 2019; National portal of India, 2019; Bank bazaar, 2019; Ramappa and Manjunatha, 2017; Ghosh, 2018; PM-Kisan Samman Nidhi, 2019; MEEN Arunachal, 2015; MIDH, 2018). 
Table 1: Details of Government initiated schemes

\begin{tabular}{|c|c|c|c|c|c|}
\hline \multicolumn{6}{|c|}{ Rashtriya Krishi Vikas Yojana (RKVY), 2007} \\
\hline Kick start Objectives & $\begin{array}{c}\text { Implementing } \\
\text { Agency }\end{array}$ & $\begin{array}{c}\text { Budget Allocation } \\
\text { in USD (Year) }\end{array}$ & Beneficiary & Present standpoints & Problems \\
\hline $\begin{array}{l}\text { Development of agriculture and } \\
\text { allied sectors. } \\
\text { To reduce the yield gaps in } \\
\text { important crops. } \\
\text { To maximize returns to the } \\
\text { farmers in agriculture and allied } \\
\text { sectors. }\end{array}$ & $\begin{array}{l}\text { Ministry } \\
\text { Agriculture } \\
\text { Farmers Welfare }\end{array}$ & $\begin{array}{l}469.5 \text { million USD } \\
(2018-2019)\end{array}$ & $\begin{array}{l}10679 \text { farmers in } \\
\text { twelve selected } \\
\text { sectors (2014) } \\
35000 \text { farmers in the } \\
\text { drought compensation } \\
\text { plan }\end{array}$ & $\begin{array}{l}\text { Budget allocated: } 4.9 \\
\text { billion USD (2007-08 } \\
\text { to } 2011-12) \text {. } \\
\text { Expenditure: } 3.0 \text { billion } \\
\text { USD for implementing } \\
7234 \text { projects } \\
\text { Unutilized: } 1.94 \text { billion } \\
\text { USD (by the end of } \\
11 \text { th FYP). } \\
80 \% \text { of the total } \\
\text { expenditure } \\
\text { concentrated in only } 8 \text {, } \\
\text { out of } 20 \text { sectors. }\end{array}$ & $\begin{array}{l}\text { Underutilization of funds. } \\
\text { Limited number of sectors } \\
\text { covered. } \\
\text { More than } 55 \% \text { of the } \\
\text { projects were initiated after } 2 \\
\text { years of implementation of } \\
\text { the scheme. }\end{array}$ \\
\hline
\end{tabular}
Paramparagat Krishi Vikas Yojana (PKVY), 2015

To conduct model organic Ministry of 18.05 million USD 48949 farmers Average cost per Insufficient funds/ delay in cluster demonstrations at Agriculture \& (2017-2018) farmer's field. Farmers Welfare

To promote organic farming and to disseminate the latest technologies regarding organic farming.

\section{\& (2017-2018) 2,25,635 involved in hectare in paddy is fund release.}

organic farming reduced due to organic Only encouraging input (2016-17) agriculture by $17.2 \%$, companies rather than while gross returns farmers. decreased by $9 \%$. PKVY guidelines are not The yield of organic flexible, enough state agriculture was less requirements.

than conventional by Existing organic farmers $9.1 \%$ were selected who were already part of other schemes.

Pradhan Mantri Krishi Sinchai Yojana (PMKSY), 2015

To enhance the physical access Ministry of 456.54 million USD 19,17,952 farmers PMKSY contradicts In Maharashtra, most of the of water (Har Khet ko pani). Agriculture \& (2019-20) from 2016-17 to 2019- with the National Water projects are still pending

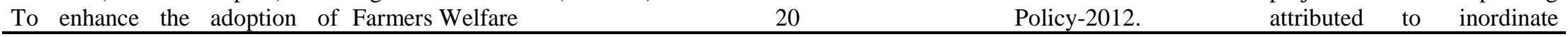




\begin{tabular}{|c|c|}
\hline $\begin{array}{l}\text { precision - irrigation and other } \\
\text { water-saving technologies (More } \\
\text { crop per drop). } \\
\text { To introduce sustainable water } \\
\text { conservation practices. } \\
\text { To ensure the integrated } \\
\text { development of rainfed areas. }\end{array}$ & $\begin{array}{l}\text { Capital intensive delays and allegations of } \\
\text { technology to elite corruption. } \\
\text { farmers has created } \\
\text { informal water markets } \\
\text { and this has destroyed } \\
\text { the Indian irrigation } \\
\text { system. }\end{array}$ \\
\hline
\end{tabular}
development of rainfed areas.

To provide insurance coverage Ministry and financial support during Agriculture crop loss resulting from natural Farmers Welfare calamities, pests and diseases.

To stabilize the income of

farmers to ensure their continuous process in farming.

\section{Pradhan Mantri Fasal Bima Yojana (PMFBY), 2016}

of 1.82 billion USD 18,54,43,390 farmers The benefit of all the Bihar, Assam and North\& (2019-2020)

from 2016-17 to 2019- crop insurance schemes eastern states lagged in 20. was availed by farmers availing the benefits of crop of Gujarat, insurance.

Maharashtra, Andhra Individual farmers suffering Pradesh and Madhya losses are not going to Pradesh. Their share benefit unless the entire area was nearly $80 \%$ of the gets affected.

claims paid in the

country.

The scheme will

continue to be on 'area

approach basis' -

village/village

Panchayat for major

crops and the area

above that level for

other crops.

\section{Soil Health Card Scheme (SHC) (2015)}

Healthy Earth, Green Farm. Ministry of 42 million USD Total no. of samples The same fertilizers SHC has been issued to Testing the quality and type of Agriculture \& (2019-2020)

soil.

collected in Cycle I were recommended for certain farmers without soil and II: 5,21,81,553 every farm. testing.

A significant There is no one method of Total no. of samples reduction (20-30\%) treating the soil that applies tested: $5,19,25,197$ was observed in the to all farmers. use of Urea and DAP

Total no. of SHC in paddy and cotton. 


\section{distributed in cycle I Cost of cultivation \\ and II: $21,24,98,902$ was reduced from 13- \\ 52 USD per acre.}

\section{National Mission for Sustainable Agriculture (NMSA), 2013}

To make agriculture more Ministry
productive,
remunerative and climate- Farmers Welfare
resilient.

resilient.

To adopt comprehensive soil health management practices.

To optimize the utilization of water resources ('more crop per drop').

of 161.35 million USD 544 farmers (National The proposed strategies The proposed strategies are \& (2018-2019) Bamboo Mission). of the mission given targeting only the big

To provide insurance against crop loss resulting from adverse Agricult

weather conditions. $\quad$ Farmers Welfare

$$
\text { importance only to farmers. }
$$

\section{$2,43,233$ in Rainfed water and largely}

Area Development ignored the usage of Further, the scheme could from 2016-17 to 2019- chemical fertilizers. not combat the challenges 20. The use of chemical faced by agriculture due to fertilizer required more climate change.

4536 (Sub-mission on irrigation as compared

agroforestry). $\quad$ to organic farming.
Weather Based Crop Insurance Scheme (WBCIS)/ Restructured WBCIS, 2015/2016

of 91.3 million USD 15 lakh farmers have The budget allocated Non-coverage of perils other \& (2013-2014)

been insured in Kharif have been completely than weather.

utilized.

All the claims are

settled within the

shortest possible time.

\section{Livestock Insurance Scheme, 2005}

To provide insurance protection Ministry of 3.91 million USD 7.44 lakh animals A loss ratio of $>150 \%$ Lengthy claims settlement to cattle rearers against income fisheries, Animal (2011-2012) insured during 2016- was observed during the process.

losses due to the death of their Husbandry and 17 valuation and Poor

animals. $\quad$ dairying

identification of cattle infrastructure.

To attain qualitative

due to poor monitoring

improvement in livestock and

processes.

their products.

To provide basic amenities like Ministry

National Scheme on Welfare of Fishermen, 2002

drinking water and sanitation to Agriculture

of 83.48 million USD 3.5 lakh fishers Incomplete

covered under saving- registrations,

cum-relief; 3 lakh internal control.

improve the living standard of

fishermen under group Government did not 
To provide social security for
active fishers and their

$$
\begin{array}{llr}
\text { accident insurance; } & \text { consider } & \text { the } \\
6400 \text { fishermen per } & \text { deteriorating situation } \\
\text { year under training of the Pilot Prawn } & \text { hatchery to avoid } \\
\text { and extension. } & \begin{array}{l}
\text { harther infructuous } \\
\text { expenditure. }
\end{array}
\end{array}
$$

\section{Neem coated urea (NCU), 2015}

$\begin{aligned} & \text { About } 248 \text { Lakh Metric Ton of Government of } 53,629 \text { have been Around 23000dealers Difficult to differentiate The price of NCU is higher } \\ & \text { indigenously manufactured urea India }\end{aligned}$ allocated to urea have been benefitted. between NCU \& NU. than plain urea.
indigenously manufactured urea India

will be made available to subsidy in 2019

farmers at the statutory MRP

notified by the Government.

Reduction in a diversion of urea

towards a non-agricultural

purpose.

No training on the crop- Due to a lack of irrigational wise application of facilities, the desired benefits NCU. of NCU are not extracted.

Dairy Entrepreneurship Development Scheme (DEDS), 2005-2006

To promote setting up of modern National Bank for 42.39 million USD 32,581 farmers have A significant increase In the Western Region, dairy farms for the production of Agriculture and (2019-2020) clean milk.

Rural

Development

To encourage heifer calf rearing, (NABARD)

thereby conserving good

breeding stock and to upgrade the quality and traditional technology to handle milk on a commercial scale. been benefitted from of around $123 \%$ in Private

$(1.04 .2018$

28.02.2019).

beneficiary

overall average milk Banks are charging a lower production

per interest rate than the nationalized banks.

Further, 2 lakh people entrepreneur has been (Ratnakar Bank $-11.25 \%$ for have been employed

observed. 3 years).

SC/ST subsidy is under- Bihar, MP, Gujarat, utilized in several Maharashtra, Jharkhand \& States. Kerala have reported less than $10 \%$ of $\mathrm{SC} / \mathrm{ST}$ beneficiaries.

PM-Kisan Samman Nidhi Yojana (PM-KSNY), 2018

To support farmers whose Ministry of 9.7 billion USD 2,60,000 00 (2018- According to the About $60 \%$ of eligible income is insufficient for their Agriculture \& (2019-20) Agriculture department, farmers are deprived of the sustenance $\quad$ Farmers Welfare 8,50,00000 (2019-20). 6.68 lakh payments PM Kisan Samman Nidhi failed while paying the benefits as the States have first installment while not added them to the list of 1.32 lakh failed during beneficiaries. 
the second installment.

West Bengal has not yet

registered a single

farmer for the scheme

National Food Security Mission (NFSM), 2007

To increase the production of Ministry of 260.88 million USD 18,08,216 from 2016- In 2007-08, NFSM was Total area under rice rice, wheat, pulses, coarse Agriculture \& (2019-20) 17 to 2019-20 implemented in 482 cultivation declined from cereals (Maize and Barley) and Farmers Welfare

Nutri-cereals

To restore soil fertility and productivity at the individual farm level

To enhance farm level economy districts of 19 states $\quad 44.92$ (2007-08) lakh ha to The production of rice, 44.00 lakh ha (2011-12)

wheat and pulses has

been increased from In FY2015-16, 1279.15 93.36, 75.81, 14.2 crores have been allocated, (2006-07) to 105.31 , of which only 573-19 crores 94.88 and 17.09 million have been utilized tonnes (2011-12).

\section{National Livestock Mission (NLM), 2014-15}

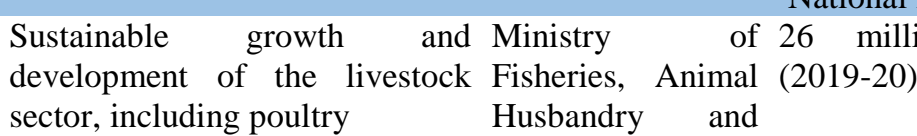

sector, including poultry Husbandry and

To increase the availability of Dairying

fodder and feed to substantially

reduce the demand-supply gap

Entrepreneurship

Development

Employment

Generation (EDEG).

3.68 lakh beneficiaries

under Rural Backyard 3823 silage

Poultry Development established

35.64 lakh animals 519 Livestock Melas

have been insured have been

Organized

223 Livestock Farmers

Group and 121 Farmers

Field Schools have been

established

Rashtriya Gokul Mission (RGM), 2014

Development and conservation Ministry

of indigenous breeds

Fisheries,

To enhance milk production and Husbandry of 97.83 million USD 1,26,47,471 animals 20 Gokul Grams have Each 'Gokul Gram' was nimal (2019-20)

and have been registered been
in various states and states
200 hectares and house 1000 


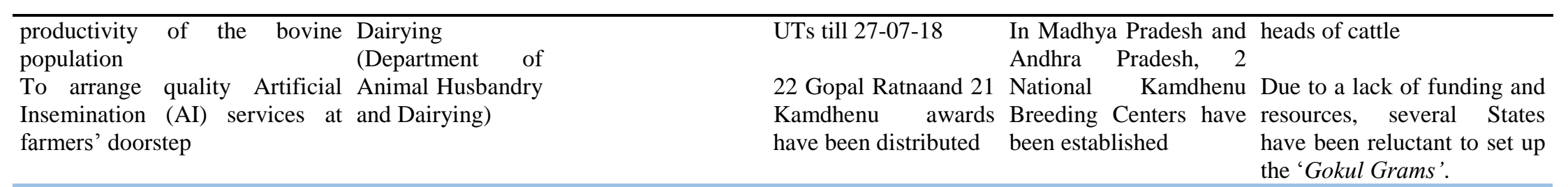

The scheme on Development of Inland Fisheries and Aquaculture-Blue Revolution, 2014-15

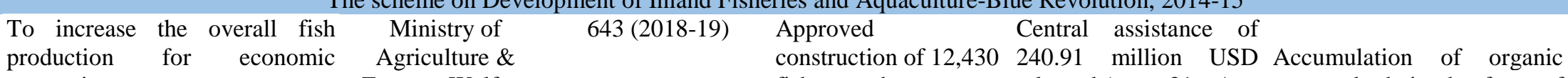

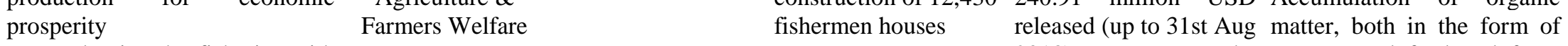

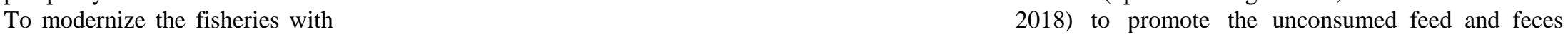

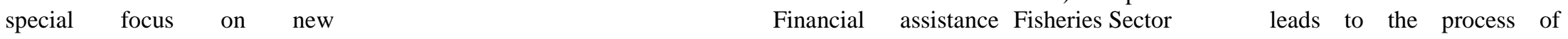

technologies

provided to 2.43 lakh Assistance provided for eutrophication

fishermen annually bringing $29,127.73$ ha

under Saving-cum- area under aquaculture

Relief component Approved establishment

during fishing of 389 of fish/prawn

lean/ban period hatcheries

Mission for Integrated Development of Horticulture (MIDH), 2014-15

To promote holistic growth of Ministry of 290 million USD 5,13,054 from 2016- Organic cultivation is During the $11^{\text {th }}$ plan, an

the horticulture sector, including Agriculture \& (2019-20) 17 to 2019-20

bamboo and coconut Farmers Welfare

To enhance horticulture

production, augment farmer's

income and strengthen

nutritional security

To support skill development

and create employment

generation opportunities for

rural youth in horticulture

Organic cultivation is During the $11^{\text {th }}$ plan, an
adopted in 1.51 lakh ha, amount of 1.14 billion USD in seven States. was approved for the Karnataka has implementation of the established $\quad 420$ scheme. Against this, an nurseries accounting for amount of 482.4 million a $19 \%$ share followed USD was released up to by Kerala $13 \%$ while 2010-11 and an amount of Tamil Nadu, Orissa, 571 million USD was spent MP, AP have that includes the unspent accomplished 7-8\%. balance amount of 92.6 million USD of $10^{\text {th }}$ plan. 


\subsection{Analysis of growth in the agriculture sector}

In 2018-19, the Agriculture Ministry has been allocated 7.5 billion USD and the amount was $14.6 \%$ more than the revised estimate in 2017-18. A major section of the Union budget has predominantly focused on subsidies. In 2016-17, the allocation under the Ministry observed a sudden increase due to the initiation of the 'Interest Subsidy Scheme' which is currently being accounted under the Ministry of Agriculture from 2016-17, previously it was used to be considered under the Finance Ministry.

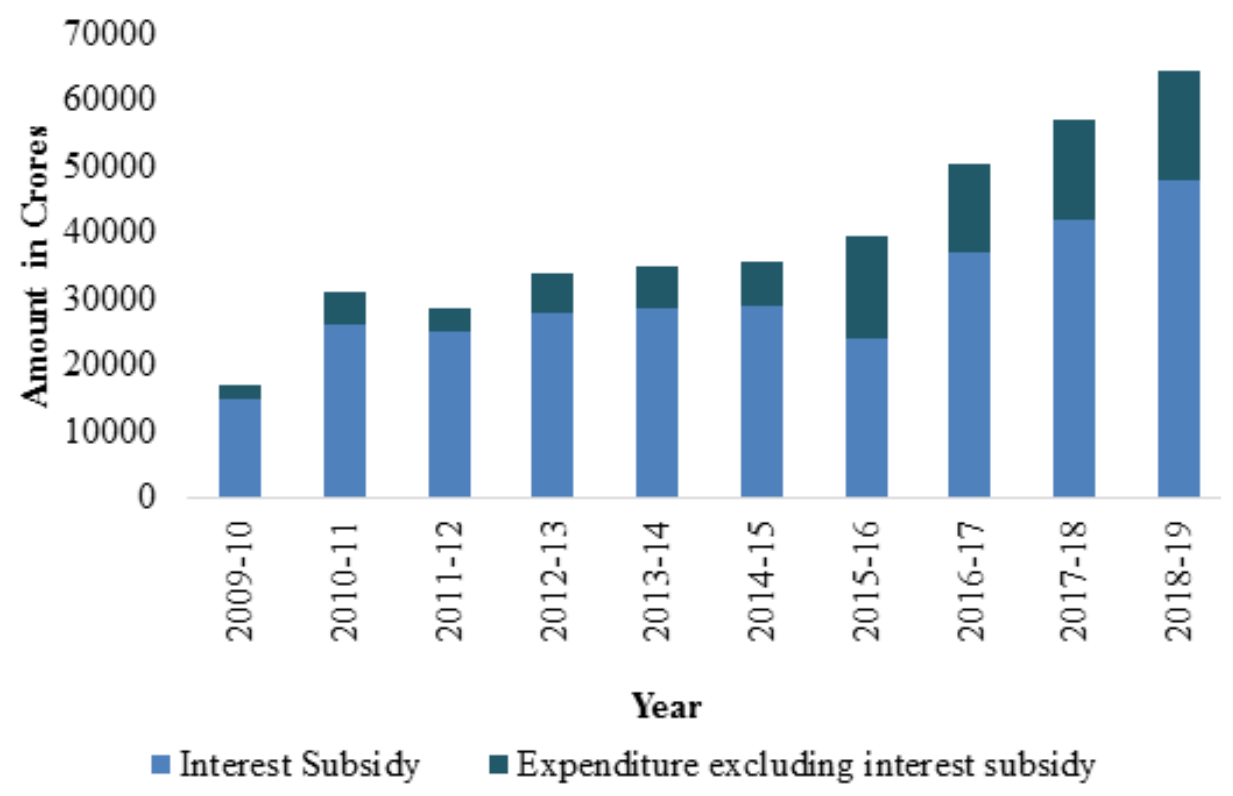

Figure 5: Year-wise expenditure of government over the subsidies

When a reality check was carried out between the allocated budget and actual expenditure it was observed that in 2017-18, the allocated budget was revised down by $1.5 \%$ (Figure 5). Between the tenure of 2009-10 and 2015-16, the actual expenditure was observed to be lesser than the budgeted expenditure, except for the years 2010-11 and 2016-17. Report of the standing committee on agriculture (2016) reveals that reducing allocated budget at the later stages may be a result of slow spending in the first two quarters of the financial year which reveals that there is no uniform distribution of funds and nor its release is uniform (Figure 6) (Hansen, 2016). 


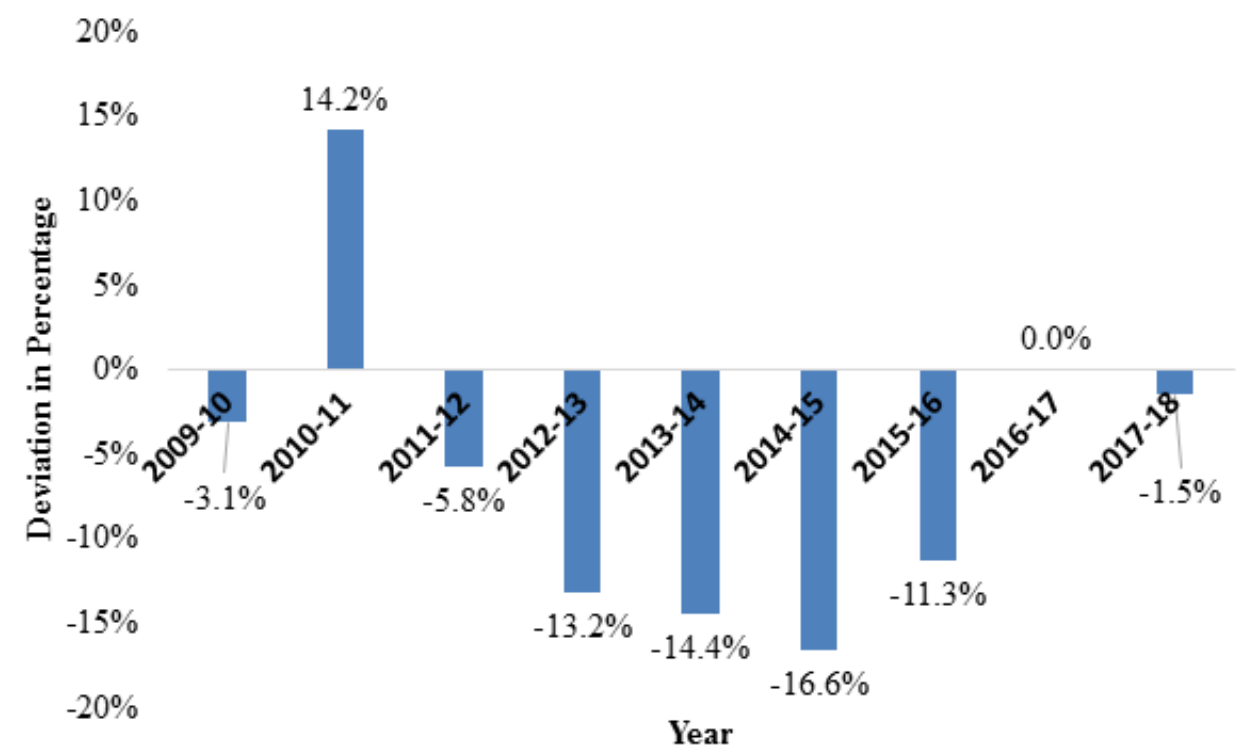

Figure 6: Deviation from budgeted expenditure

\subsubsection{Departmental expenditure}

About $82 \%$ of this allocated budget is proposed to be spent on five schemes. These are the Interest Subsidy Scheme (32\%), Pradhan Mantri Fasal Bima Yojana (28\%), Pradhan Mantri Krishi Sinchayi Yojana (9\%), Rashtriya Krishi Vikas Yojana (8\%), and National Mission of Horticulture (5\%) because of which the other sections remained deprived of financial benefits.

A decline in the contribution of agriculture and allied sectors towards the country's economy has observed from $18.2 \%$ in $2012-13$ to $16.5 \%$ in $2017-18$. Furthermore, the growth in the agriculture sector has remained volatile over the past few years. In $2017-18,2.1 \%$ of reduction in growth rate was observed in comparison to 2016-2017. Within the agriculture sector also, variation in the contributing share of the crop sector is observed which declined from 65\% in 2011-12 to 60\% by 2015-16.

Under-utilization of funds has also remained a matter of concern. The Standing Committee on Agriculture (2017) observed that funds under the PMKVY reduced drastically and continuously between 2012 and 2017. 70.43 million USD allocated to the scheme in 2016-17 and out of it 507.6 million USD were released. A shortfall of around $28 \%$ in the released amount was observed furthermore out of this released amount, only around 443.50 million USD was utilized. The committee also noticed that only 12 States have prepared state agriculture plans till February 2017 which is needed for the implementation of the scheme. 38\% of district agriculture plans have been prepared so far which are needed to be approved on a priority basis without any further delay to avoid a reduction in the allocated amount at later stages (Rathi, 2018).

\subsection{Analysis of government policies on agriculture: a reflective study}

The Comptroller and Auditor General of India (CAG) in their 2015 annual report revealed that the total RKVY budget allocation from 2007-08 to 2011-12 was 4.9 billion USD. The expenditure acquired was 3.0 billion USD for the implementation of 7234 projects initiated under RKVY. The allocation ratio for the expenditure was observed to be 0.61 which revealed that they had an unutilized amount of 1.9 billion USD at the end of the 11th financial year programme. The maximum expenditure allocation ratio was identified as 0.72 in South India and the minimum ratio of 0.57 was noted in East and North East India (CAG Report, 2018). 
CAG reported that 100 projects got abandoned in India and out of these 28 projects were in Andhra Pradesh, Kerala, Rajasthan, Sikkim and Uttar Pradesh. An in-depth analysis revealed that the major reason behind this is the non-availability of staff, non-viability of the project, improper release of funds, unresponsive behavior of beneficiaries and Ministry has already spent 17.6 million USD on these dropped projects which reflected that this money went in waste. In Punjab which is commonly called as the food basket of India, Ministry has released 5.81 million USD, which is slightly lesser than the total allocation of 11.73 million USD and this amount has also not been utilized so far. A similar movement of money was observed in Bihar, Telangana and Jharkhand. 99 million USD was found parked in personal ledger accounts in 11 States. CAG report revealed that expenditure of 13.84 million USD was found to be indulging in 50 projects in seven States without taking any prior permission from the State Level Sanctioning Committee (SLSC).

When PMKSY was analyzed, it was observed that the benefit of the scheme was restricted to only a few States and only 5 out of 16 projects were under implementation. The remaining 11 projects were yet to be commenced because of approval issues. These 5 projects were originally started during 1975-1983 which indicated that there exists an implementation delay for four decades. An audit also underlined the hidden facts behind these 5 projects and revealed that these projects have not yet achieved the stage from where the common man can be benefitted. CAG reported that the Government has initiated several schemes for promoting organic produce but ground truthing revealed that they have not provided a steady market to the farmers for this. There exists a threatening shortage of good quality organic input thereby enhancing risk towards loss of yield. Currently, the available quantity of organic fertilizers is far beyond the desired limits furthermore presence of spurious players in the market makes the situation more complicated. Ongoing supply chain in organic farming is underdeveloped and it is highly difficult for small scale farmers to access the market and they are deprived of financial benefits from the Government to improve the current scenario (CAG Report, 2018).

\section{SWOT ANALYSIS OF INPUT IN INDIAN AGRICULTURE}

Strength, weakness, opportunities and threats of various schemes and policies have been critically analyzed to understand the gap between policymakers and farmers (CAG Report, 2018; Ghosh, 2018; MIDH, 2018; Business standard, 2019). 
Table 2: Evaluation of strength, weakness, opportunities and threats of Government initiated schemes

\begin{tabular}{|c|c|c|}
\hline Strength & Opportunities & Threat \\
\hline $\begin{array}{l}\text { Government subsidy bill on food, } \\
\text { fertilizer, fuel is estimated to be } \\
\text { enhanced by } 13.32 \% \text { to } 39.35 \text { billion } \\
\text { USD in } 2019-2020 \text { to benefit a larger } \\
\text { population }\end{array}$ & $\begin{array}{l}\text { of } \begin{array}{l}2,25,14,611 \\
\text { benefitted fromers have been } \\
\text { fransfer }\end{array} \\
\text { Trarect Benefit }\end{array}$ & 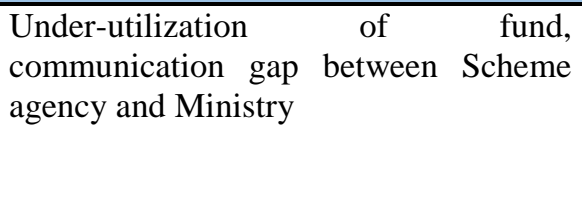 \\
\hline $\begin{array}{l}\text { RKVY incentivized the States to } \\
\text { increase public investment in } \\
\text { agriculture and allied sectors. }\end{array}$ & $\begin{array}{l}\text { To RKVY } 704 \text { billion USD allocated } 10679 \text { farmers in twelve selected } \\
\text { in 2016-17, } 507 \text { million USD were sectors, } 35000 \text { farmers have been } \\
\text { released, out of this released amount benefitted in drought compensation } \\
\text { only } 443.5 \text { million USD was utilized plan in } 2014\end{array}$ & $\begin{array}{l}\text { According to the CAG report, the } \\
\text { expenditure reported by the scheme is } \\
\text { different from the expenditure reported } \\
\text { by the Ministry }\end{array}$ \\
\hline $\begin{array}{l}469 \text { million USD (2018-2019) have } \\
\text { been allocated only to RKVY }\end{array}$ & $\begin{array}{ll}\text { More than } 55 \% \text { of the projects were } & \text { RKVY is currently focusing on a } \\
\text { started after } 2 \text { years of the launch of limited number of the sector which } \\
\text { the project. } 80 \% \text { of the total budget can be further elaborated to provide } \\
\text { was concentrated on only } 8 \text { States. }\end{array}$ & $\begin{array}{l}\text { CAG auditors said that the execution of } \\
\text { projects was marked by administration } \\
\text { delays, poor contact management, and } \\
\text { improper monitoring. }\end{array}$ \\
\hline $\begin{array}{l}\text { In Anantapur, Andhra Pradesh } \\
1,41,975 \text { farmers have been } \\
\text { benefitted with an average increase } \\
\text { of } 31.8 \% \text { in their annual income } \\
\text { under Pradhan Mantri Krishi Sinchai } \\
\text { Yojana }\end{array}$ & $\begin{array}{l}\text { Most of these projects have not been } 19,17,952 \text { farmers have been } \\
\text { completed till now and the majority benefitted from 2016-17 to 2019-20 } \\
\text { of incomplete projects lies in } \\
\text { Maharashtra face inordinate delays } \\
\text { and allegations of corruption }\end{array}$ & $\begin{array}{l}\text { Capital intensive technology to elite } \\
\text { farmers has created informal water } \\
\text { markets and this has destroyed the } \\
\text { Indian irrigation system. } \\
\text { PMKSY contradicts the National Water } \\
\text { Policy-2012, formulated by the } \\
\text { Government itself }\end{array}$ \\
\hline $\begin{array}{l}\text { PMFBY is one of the World's largest } \\
\text { crop insurance programs aimed at } \\
\text { providing risk cover to Indian } \\
\text { farmers from } \\
\text { vulnerabilities }\end{array}$ & $\begin{array}{l}80 \% \text { of the claims have been availed } 18,54,4 \\
\text { by only } 4 \text { states. Bihar, Assam and benefit } \\
\text { North-eastern state lagged in availing } \\
\text { the benefits of crop insurance leading } \\
\text { to the mercy state of farmers of that } \\
\text { particular region. }\end{array}$ & $\begin{array}{l}\text { The scheme will continue to be on 'area } \\
\text { approach basis'-village/village } \\
\text { Panchayat for major crops and the area } \\
\text { above that level for other crops. The } \\
\text { individual farmers suffering losses are } \\
\text { not going to be benefitted unless the } \\
\text { entire area gets affected }\end{array}$ \\
\hline $\begin{array}{l}\text { Soil health card scheme resulted } \\
\text { in a significant reduction in the } \\
\text { use of Urea and DAP by } 20-30 \% \\
\text { in paddy and cotton in some } \\
\text { states. }\end{array}$ & $\begin{array}{l}\text { There is no one method of treating } 21,24,98,902 \text { Soil health cards have } \\
\text { the soil that applies to all farmers. been distributed } \\
\text { The basic soil quality varies } \\
\text { depending on the crop cycle, different } \\
\text { soil treatments that affect the }\end{array}$ & $\begin{array}{l}\text { Soil health card has been issued to } \\
\text { certain farmers without even testing the } \\
\text { soil of their farms. Same fertilizers are } \\
\text { recommended for every farm of a } \\
\text { region. }\end{array}$ \\
\hline
\end{tabular}




\begin{tabular}{|c|c|c|}
\hline & $\begin{array}{l}\text { micronutrients and the micro- } \\
\text { fauna/flora }\end{array}$ & $\begin{array}{l}\text { Chemical analysis for } \mathrm{N}, \mathrm{OC}, \mathrm{P}, \mathrm{K} \text { and } \\
\text { micronutrients only indicate their } \\
\text { availability without reflecting the soil } \\
\text { fertility }\end{array}$ \\
\hline $\begin{array}{l}\text { PM Kisan Samman Nidhi Yojna } \\
\text { support farmers whose income is } \\
\text { insufficient for their sustenance }\end{array}$ & $\begin{array}{l}\text { About } 60 \% \text { of eligible farmers are } 2,60,00000 \text { farmers during 2018-19 } \\
\text { deprived of the benefits as the States and } 8,50,00000 \text { during 2019-20 have } \\
\text { have not added them to the list of been benefitted are more are getting } \\
\text { beneficiaries. }\end{array}$ & $\begin{array}{l}6.68 \text { lakh payments failed while paying } \\
\text { the first installment while } 1.32 \text { lakh } \\
\text { failed during the second installment. }\end{array}$ \\
\hline
\end{tabular}




\section{AN APPROACH TOWARDS DIGITALIZED AGRICULTURE: TRACEABILITY, AVAILABILITY AND TRANSPARENCY}

Addressing the challenges in agriculture needs a transformation strategy rooted in technological advancement (Tinh et al., 2019). The agriculture sector lags far behind in the adoption of technology, despite the urgent need to look for the solution to rectify the current issues as mentioned in previous sections of the article. Despite availability, there is unequal access to the solution. The concept of traceability, availability and transparency merged with updated technology may act as an effective measure to overcome the issues associated with agriculture.

Agricultural traceability indicated the compilation and maintenance of documents related to the supply chain process thereby ensuring the guarantee of product between producer and consumer. History of a product can be easily traced during the period of its crisis and the Government can have a better hold over its policies and schemes initiated for farmers' welfare and over the hoarding and wastage issues majorly responsible for it. Whereas agriculture transparency deals with the idea of affirmation of the quality of a product by determination of product certification at every step of the supply chain. This data is useful in ensuring, whether the Government's initiatives have been implemented as per the suggested directions or are getting extorted to benefit a specific section. When it comes to availability, it affirms the direct communication between the farmer and the Government regarding the availability and needs to produce thereby providing actual reimbursement of their labor and produce (Opara, 2003).

\subsection{Proposed ICT based mechanism of traceability, availability, and transparency for sustainable agriculture}

To overcome this issue, a team of Scientists in Patanjali Research Institute Haridwar, India is currently working on it and has prepared a proposed framework underlined as 'Information and communications technology (ICT) based mechanism of traceability, availability, and transparency for sustainable agriculture'. The proposed mechanism will act as a central repository body to keep farmers, consumers and Governmental bodies in one ring to develop a mirrored view between Government's initiatives for farmers, production, and consumption of agriculture products (Figure 7).

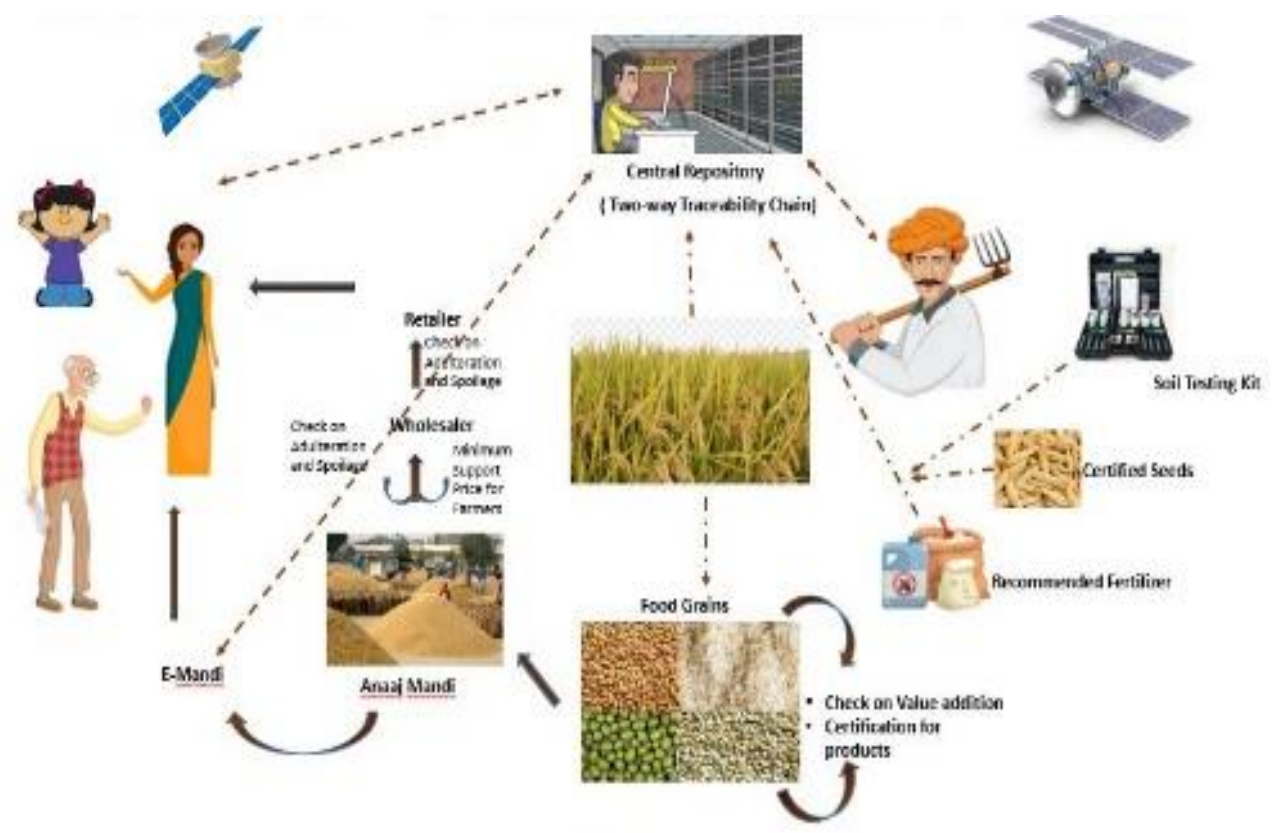

Figure 7: A digitalized mechanistic approach towards sustainable development 


\section{CONCLUSION}

The country's economy plays a vital role in formulating it to be self-sufficient in food grains. The divergence between production and availability is reflected from weeping eyes due to hunger. Despite a significant hike in budgetary allocation for agriculture, the farmer's state has remained the same for several decades in the history of Indian agriculture. We have acutely monitored the agriculture status of India and found that there exists a massive gap between the Agriculture Ministry of India and a farmer, depicting the reason why the promises and dreams of Government remained unachievable probably due to insufficient hold over food hoardings, adulteration, and food wastage. Despite the initiation of more than 17 schemes at the National level and several others at the State level, the number of beneficiaries freezes to few restricted States and countable communities. Under-utilization of funds, improper/delayed drafting of agriculture plans, and communication gap between scheme agency and Ministry have remained a major reason for failure. CAG report revealed that several projects abandoned after the initiation due to non-viability of project, short release/non- availability of funds, the unwillingness of beneficiaries and because of which huge sum of money wasted which reflects the long tenure errors committed by policymakers after independence in shaping the schemes or policies of Indian agriculture. Absurdity made by Government needs to be rectified with immediate action against the impoverished state of farmers for the better growth of the Indian economy. The attempts initiated by the current Government to uplift the status of organic agriculture and permitting the farmer to directly relate their products with the consumer, are highly appreciable. We believe that the positive modifications made by the current policymakers will help to boost the economic status of Indian farmers and will prove as a boon for Indian agriculture in the coming future. Further, we emphasize the digitalized mechanistic approach for sustainable agriculture and to benefit the farmers.

Funding: This study received no specific financial support.

Competing Interests: The authors declared that they have no conflict of interests.

Contributors/Acknowledgement: The authors are grateful to Param Pujya Swami Ramdev for the institutional and research supports. The authors gratefully acknowledge the efforts of all the colleagues of the Patanjali Research Institute (PHRD), for their help in data collection and analysis. They are also thankful to Mr. Lalit Mohan and Mr. Gagan Kumar for their swift administrative supports and encouragement.

Views and opinions expressed in this study are the views and opinions of the authors, Asian Journal of Agriculture and Rural Development shall not be responsible or answerable for any loss, damage or liability, etc. caused about/arising out of the use of the content.

\section{References}

Amarender, R. A. (2017). Impact study of Paramparagat Krishi Vikas Yojana. National Institute of Agricultural Extension Management.

Bank bazaar (2019). National scheme on welfare of fishermen. Retrieved from https://www.bankbazaar.com/saving-schemes/national-scheme-on-welfare-offishermen.html.

Business standard (2019). 20 lakh farmers expected to benefit as PMKSY expected to leverage investment of Rs 31400 crore. Retrieved from https://www.businessstandard.com/article/news-cm/20-lakh-farmers-expected-to-benefit-as-pmksy-expected-toleverage-investment-of-rs-31400-crore-119062600619 1.html.

CAG Report (2018). Report of the comptroller and auditor general of India on accelerated irrigation benefits programme. Report No. 22.

Chait, J. (2019). What is the definition of an agricultural product?. The balance small business. Retrieved from https://www.thebalancesmb.com/what-is-an-agricultural-product-2538211.

Deshpande, T. (2017). State of agriculture in India. PRS Legislative Research India. Retrieved from https://www.prsindia.org/sites/default/files/parliament_or_policy_pdfs/State\%20of\%20Agri culture\%20in\%20India.pdf. 
Ghosh, R. K. (2018). Performance evaluation of Pradhan Mantri Fasal Bima Yojana (PMFBY). Part-I Final Report.

Government of Haryana Pashudhan (2019). Department of Animal Husbandry and Dairying. Pashudhan Haryana: Special livestock insurance scheme (SCSP) for the year 2018-19. Retrieved from http://pashudhanharyana.gov.in/activities/schemes.

Government of India (2015). MEEN Arunachal: NFDB Schemes \& Blue Revolution-Inland Fisheries Schemes. $\quad$ Retrieved from http://www.meenarun.nic.in/docs/programmes/NFDBGuideline_BlueRevolution.pdf.

Government of India (2019). Ministry of agriculture. Directorate of economics and statistics: Agricultural situation in India.

Government of India (2018). Mission for integrated development of horticulture. National Horticulture Mission. Retrieved from https://midh.gov.in/Schemes.html.

Government of India (2014). Rashtriya Krishi Vikas Yojana: Operational guidelines for XII five year plan $(R K V Y)$.

Government of India (2018). Pocket book of agricultural statistics. New Delhi, India: Government of India.

Government of India (2018). Press Information Bureau: National mission for sustainable agriculture.

Government of India (2019). Department of agriculture, cooperation \& farmer's welfare: Allocation of funds under soil health management and soil health card schemes.

Government of India (2019). Pradhan Mantri Krishi Sinchayee Yojana (PMKSY). Retrieved from https://pmksy.gov.in/.

Hansen, H. O. (2016). Agricultural policy schemes: Price and support systems in agricultural policy. In Reference Module in Food Science. Elsevier.

Indian Council for Research on International Economic Relations (2018). Agricultural policy review of India. Retrieved from https://icrier.org/pdf/Agriculture-India-OECD-ICRIER.pdf.

Karnik, A., \& Lalvani, M. (1996). Interest groups, subsidies and public goods: Farm Lobby in Indian Agriculture. Economic and Political Weekly, 31, 818-820.

Moray, R. (2019). Implication of technology on economic progress of farmers: a case of India. Development, 9(2), 179-193.

National portal of India (2019). Ministry of Agriculture: Livestock insurance scheme. Retrieved from https://www.india.gov.in/topics/agriculture.

Opara, L. U. (2003). Traceability in agriculture and food supply chain: a review of basic concepts, technological implications, and future prospects. Journal of Food Agriculture and Environment, 1, 101-106.

Planning commission government of India (2015). Organization for Economic Co-operation and Development. Agriculture Policy: Vision 2020. Retrieved from http://www.oecd.org/officialdocuments/publicdisplaydocumentpdf/?cote=TAD/CA(2018)4/ FINAL\&docLanguage=En.

PM-Kisan Samman Nidhi (2019). State wise/Installment wise list of beneficiaries counts summary report.

PRS Legislative Research (2019). Demand for Grants 2018-19 Analysis: Agriculture and Farmers' Welfare.

Ramappa, K. B., \& Manjunatha, A. V. (2017). Impact of neem coated urea on production, productivity and soil health in India. agriculture development and rural transformation Centre report, institute for social and economic change, Bengaluru, Karnataka.

Rathi, D. (2018). India's backbone is break bone. International Journal of Basic and Applied Research, 8(6), 622- 627.

Sally, M. (2018). India sets record farm output target for 2018-2019. The Economic Times. Retrieved from https://economictimes.indiatimes.com/news/economy/agriculture/india-setsrecord-farm-output-target-for-2018-19/articleshow/65858058.cms.

Sharma, K. G. (2004). Agricultural input subsidies in India: quantum of subsidies to SC/ST farmers in Madhya Pradesh \& Chhattisgarh. Agro - Economic Research Centre For Madhya Pradesh And Chhattisgarh J.N.K.V.V., Jabalpur (M.P.) 
Tinh, L., Hung, P. T. M., Doan, G. D., \& Trinh, V. H. D. (2019). Determinants of farmers intention'of applying new technology in production: The case of VietGAP standard adoption in Vietnam. Asian Journal of Agriculture and Rural Development, 9(2), 164-178. 